\title{
Selfie Tourism and Electronic Word of Mouth: Does Age and Gender Matter?
}

\author{
Okki Trinanda ${ }^{1}$, Astri Yuza Sari ${ }^{2}$ \\ ${ }^{1}$ Universitas Negeri Padang, Padang, Indonesia, $\square$ okki.trinanda@fe.unp.ac.id \\ ${ }^{2}$ Universitas Negeri Padang, Padang, Indonesia, $\bowtie$ astriyuza@gmail.com
}

\begin{abstract}
This study aims to investigate whether Age and Gender would moderate the influence between Selfie Tourism and Electronic Word of Mouth. This research was motivated by curiosity, whether there were certain age groups who were more active in using social media when traveling, and whether gender also moderated these behaviors. To answer the research questions, the authors took a sample of 457 tourists in West Sumatra; Padang, Bukittinggi, Batusangkar, and Payakumbuh, which is considered to have many tourist destinations that was already shared in social media. The primary data was then processed by using Structural Equation Modeling.
\end{abstract}

Keywords: Selfie Tourism, Electronic Word of Mouth, Age, Gender

\section{Introduction}

Along with the popularity of digital media and the internet, especially smartphones, photography and tourism have become inseparable. Smartphones provides platform for travelers to share directly about their experiences during their touristic activities. This is phenomenon would later be known as "selfies" (Dinhopl \& Gretzel, 2015). Selfie is an activity, where someone takes their own pictures, preferrably with an interesting background as a token that he/her has already visits a destination or has an interesting experience. Initially, selfie exclusively known as a form of narcissistic behavior, but now it has become a regular activity in every tourist activity (Sigala, 2018).

Selfie phenomenon has produced a new concept, "Selfie Tourism" (Arpaci, Yalçın, Baloğlu, \& Kesici, 2018). It is a modern tourist activity when someone visits a destination, takes a picture, then shares it with an audience through social media. Furthermore, selfie tourism revolutionizes tourist behavior, where initially it was only a sight seeing tourism, turned into communication with others in the form of Electronic Word of Mouth (Chang, Li, Loh, \& Chua, 2019).

Evolution of tourist behavior certainly demands destination managers to change and adapt their strategies. It's not enough just by merely relying on a beautiful scenery, great service, good culinary and so on, but the managers must also be able to provide good locations or objects for selfies. Especially there is a tendency that an interest in visiting a tourist location is driven by information obtained from social media. Photos of beautiful and "Instagramable" tourist destinations would encourage people to visit the location (Mostafanezhad \& Norum, 2018).

In addition, selfie tourism that able to trigger Electronic Word of Mouth will eventually produce virality on the internet (Kulkarni, Kalro, Sharmaa, \& PiyushSharma, 2019). This is a condition where a tourist spot is discussed intensely by the netizens. So that keywords related to the location of the tour became a trending topic. A selfie, or other terms that can be used to explain this activity, is usually a photograph: a pictorial image produced by a camera.

It can be concluded that a selfie is an activity of phototaking carried out individually or in groups, with it/ themself as the main object (Dinhopl \& Gretzel, 2015). Selfie in tourism is actually not a new activity. In the past, tourists has already relied on celluloid cameras with a limited number of film rolls, so photos were taken only at certain times. Furthermore, these photos are only enjoyed by themselves or by a limited circle. In the latest developments, with smartphones and large digital memory, taking photos can be done at any time without any consideration, and can be shared instatenously.

Word of Mouth is proven to be the most effective form of marketing communication in persuading potential customers (Wardi, Abror, \& Trinanda, 2018). So in the context of tourism marketing, a lively 
Electronic Word of Mouth (creating buzz) will greatly benefit tourism managers. Therefore, this research is critical.

This research is a continuation of the authors' research in 2018, which investigates that Selfie Tourism had a positive and significant effect on the desire to revisit (Trinanda \& Mutaqin, 2019). However, it has not been discussed yet, whether age and gender would moderate the influence between Selfie Tourism and Electronic Word of Mouth.

Through this research will be answered, whether age and gender moderate the influence between Selfie Tourism and Electronic Word of Mouth? Are there certain age groups that are more dominant when posting their tourism activities on social media? And, does gender also moderate these habits?

\section{Hypotheses}

H1 : There is a positive and significant influence between Selfie Tourism and Electronic Word of Mouth

H2 : Age moderates the effect of Selfie Tourism on Electronic Word of Mouth

H3 : Gender moderates the effect of Selfie Tourism on Electronic Word of Mouth

\section{Research Framework}

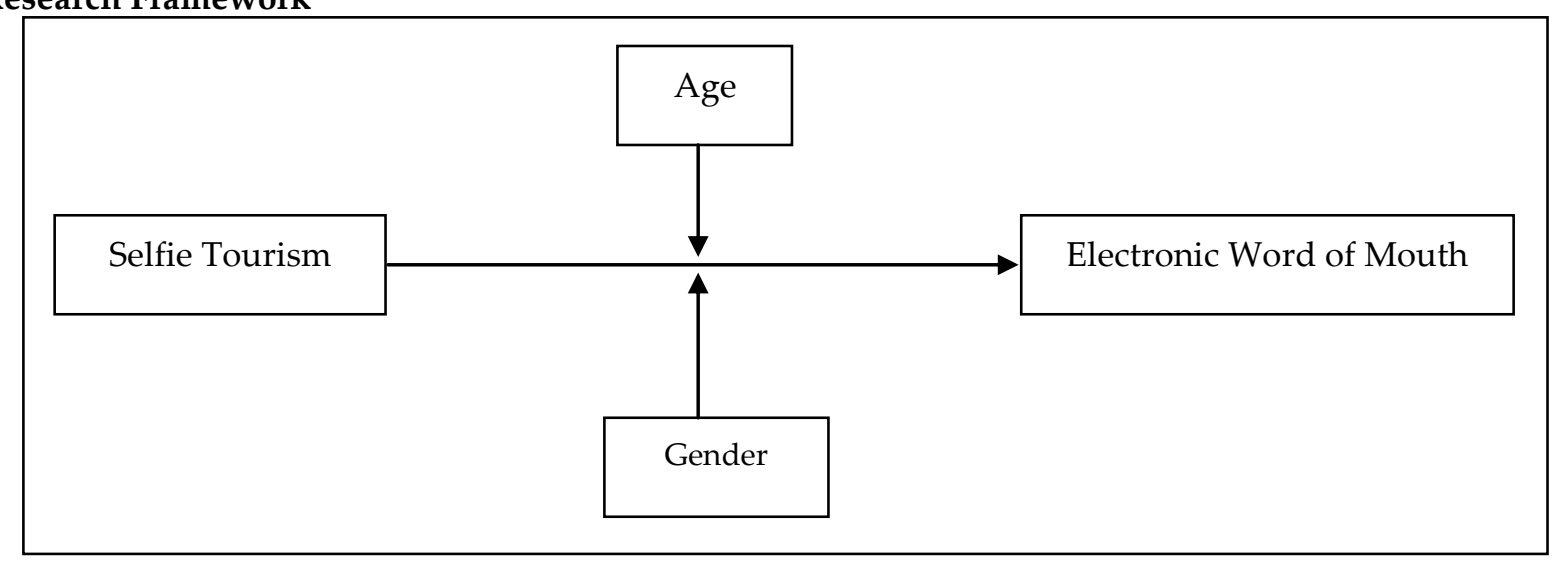

\section{Methods}

Figure 1 Research Framework

This study uses estimates based on the number of parameters obtained by the sample size of 400 respondents, but in the end the respondents obtained were as many as 457 people. The sampling technique using accidental sampling is a chance-based sampling technique, that anyone who happens to meet with a researcher can be used as a sample, if viewed as someone who happens to be found suitable as a data source (Evanita, Andriani, \& Trinanda, 2016). Respondents who will be involved in this study are foreign tourists and domestic tourists who are the first to visit tourist attractions in West Sumatra. Based on the hypothesis in this study, the data analysis method used is SEM (Structural Equation Modeling) analysis of the AMOS statistical package.

\section{Results and Discussion}

Before the distribution of questionnaires, the instrument had passed a series of tests, namely the validity test, the reliability test, the normality and multicheliarity test. From data processing, it was found that the instrument used could pass the entire test. This study also conducted confirmatory factor analysis (CFA) to improve measurement accuracy (Abror, Wardi, Trinanda, \& Patrisia, 2019). Therefore, there are several statement items that were deleted. 
Table 1 Validity and Relialibility's Test

\begin{tabular}{lcccc}
\hline & Cronbach's Alpha & rho_A & $\begin{array}{l}\text { Composite } \\
\text { Reliability }\end{array}$ & Average Variance Extracted (AVE) \\
\hline AGE & 1.000 & 1.000 & 1.000 & 1.000 \\
\hline E-WOM & 0.870 & 0.880 & 0.920 & 0.793 \\
\hline GENDER & 1.000 & 1.000 & 1.000 & 1.000 \\
\hline $\begin{array}{l}\text { Moderating } \\
\text { Effect 1 }\end{array}$ & 1.000 & 1.000 & 1.000 & 1.000 \\
\hline $\begin{array}{l}\text { Moderating } \\
\text { Effect 2 }\end{array}$ & 1.000 & 1.000 & 1.000 & 0.000 \\
\hline $\begin{array}{l}\text { SELFIE } \\
\text { TOURISM }\end{array}$ & 0.913 & 0.917 & 0.935 & 0.741 \\
\hline
\end{tabular}

Based on the table above, it can be concluded that all items are valid and reliable because all have AVE values are above $5 \%$.

Criteria for goodness of fit structural models estimated can be fulfilled, then the next step is an analysis of the structural model relationships (hypothesis testing) as shown in the following figure

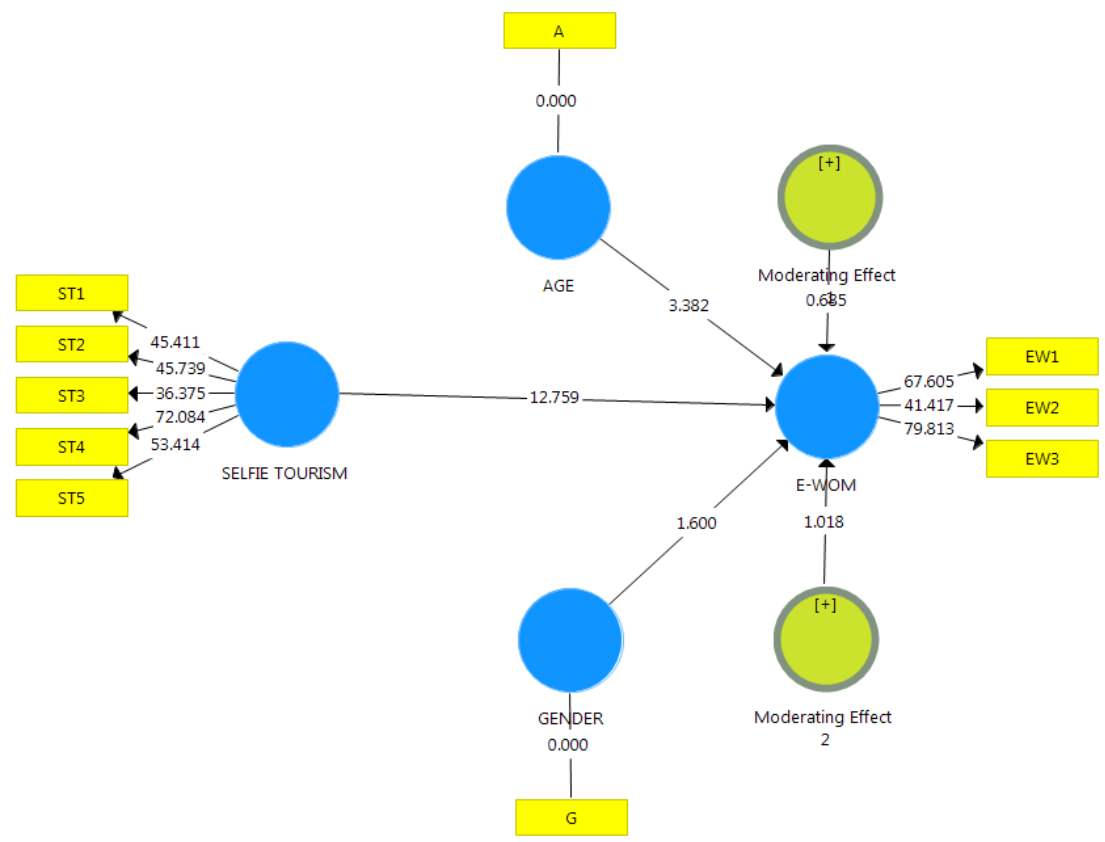

Figure 2 Structural Model Relationship

The relationship between constructs in the hypothesis is shown by regression weights values. To analyze more clearly the effect of independent variables on the dependent variable in this study, can be seen in the following table:

Table 2 Bootstrapping Results

\begin{tabular}{lccccc}
\hline & $\begin{array}{c}\text { Original Sample } \\
(\mathbf{O})\end{array}$ & $\begin{array}{c}\text { Sample Mean } \\
(\mathbf{M})\end{array}$ & $\begin{array}{c}\text { Standard Deviation } \\
\text { (STDEV) }\end{array}$ & $\begin{array}{c}\text { T Statistics } \\
(\mid \text { O/STDEVI) }\end{array}$ & P Values \\
\hline AGE -> E-WOM & -0.160 & -0.163 & 0.047 & 3.382 & 0.001 \\
\hline GENDER -> E-WOM & -0.062 & -0.060 & 0.039 & 1.600 & 0.110 \\
\hline $\begin{array}{l}\text { Moderating Effect 1 > E- } \\
\text { WOM }\end{array}$ & 0.030 & 0.025 & 0.044 & 0.685 & 0.494 \\
\hline $\begin{array}{l}\text { Moderating Effect 2 > E- } \\
\text { WOM }\end{array}$ & 0.045 & 0.046 & 0.044 & 1.018 & 0.309 \\
\hline $\begin{array}{l}\text { SELFIE TOURISM -> E- } \\
\text { WOM }\end{array}$ & 0.546 & 0.544 & 0.043 & 12.759 & 0.000 \\
\hline
\end{tabular}


Based on the data above it can be seen that age \& selfie tourism affects E-WOM (seen from $p$ value). But as moderating, age \& gender are equally debilitating (seen from the original sample value is negative) the effect of selfie tourism on E-WOM. In this case Age is a Predictor Moderating while gender is Potential Moderation.

Consistent with the results of our previous research in 2018, Selfie Tourism has a positive and significant effect on Electronic Word of Mouth. Which means, the more a tourist takes a selfie, the more likely it is that he/she will immediately share the photos on social media. The implications of this results to the tourist destination managers, they should adjust their marketing strategies that can facilitate these behaviors. In tourist destinations, interesting objects must be ready and interesting enough for a photographs, huge and attractive site brand, and other things. The aim is so that during the visit tourists make as many selfies as possible, and then they will share it on social media.

Electronic Word of Mouth has been proven to be the most effective form of marketing communication (Relling, Schnittka, Sattler, \& Johnen, 2016). Therefore, tourism managers can take advantage of this reality by utilizing selfie tourism. It can be concluded that, in the future, a successful tourist spot will not only have beautiful scenery, great service, or good food, but also because of its ability to facilitate tourist selfies (Fatanti \& Suyadnya, 2015).

Furthermore, it turns out that Age has no moderation effect on the relationship between Selfie Tourism and E-WOM. Therefore, in future studies, we will put Age as an independent variable. This means that age is one of E-WOMs'antecedents (Israeli, Lee, \& III, 2019). It seems possible that there is one particular Age group that has a tendency to use social media when traveling.

This study found that gender is a moderating variable in the relationship between Selfie Tourism and E-WOM. So it can be concluded that, there is a certain genders that tends to use social media more often than others when travelling (Mishra, Maheswarappa, Maity, \& Samu, 2018). Therefore, in the next study we will explore further, which gender among the two tends to be stronger E-WOM.

\section{Conclusions}

This study concludes that there is a positive and significant effect by Selfie Tourism towards EWOM. Therefore, tourism managers should provide tourist attractions that accommodate selfie interests. This is of course in addition to the criteria: beautiful scenery, good food, excellent service, adequate facilities, and other tourism requirements. Furthermore, from the next two hypotheses, it is found that Age is in fact not a moderating variable but is actually an independent variable, while Gender can act as a moderating variable. This finding can be used as a basis for further research, in order to develop a better research model, and can find which gender is stronger in its moderating role.

\section{References}

Abror, A., Wardi, Y., Trinanda, O., \& Patrisia, D. (2019). The impact of Halal tourism, customer engagement on satisfaction: moderating effect of religiosity. Asia Pacific Journal of Tourism Research, 24(7), 633-643. doi: https://doi.org/10.1080/10941665.2019.1611609

Arpaci, I., Yalçın, S. B., Baloğlu, M., \& Kesici, Ş. (2018). The moderating effect of gender in the relationship between narcissism and selfie-posting behavior. Personality and Individual Differences, 134, 71-74. doi: https://doi.org/10.1016/j.paid.2018.06.006

Chang, L., Li, P., Loh, R. S. M., \& Chua, T. H. H. (2019). A study of Singapore adolescent girls' selfie practices, peer appearance comparisons, and body esteem on Instagram. Body Image, 29, 90-99. doi: https://doi.org/10.1016/j.bodyim.2019.03.005

Dinhopl, A., \& Gretzel, U. (2015). Selfie-taking as touristic looking. Annals of Tourism Research(57), 126-139. doi: http://dx.doi.org/10.1016/j.annals.2015.12.015

Evanita, S., Andriani, C., \& Trinanda, O. (2016). THE RE-BRANDING OF IKIP PADANG TO UNP: HOW THE CHANGES IN BRAND AWARENESS AND BRAND IMAGE WOULD AFFECT STUDENT'S ENROLLMENT INTEREST? Paper presented at the The 1st International Conference on Economics, Business, And Accounting, Padang. 
Fatanti, M. N., \& Suyadnya, I. W. (2015). Beyond User Gaze: How Instagram Creates Tourism Destination Brand? Procedia - Social and Behavioral Sciences, 211, 1089-1095. doi: https://doi.org/10.1016/j.sbspro.2015.11.145

Israeli, A. A., Lee, S. A., \& III, E. C. B. (2019). The impact of escalating service failures and internet addiction behavior on young and older customers' negative eWOM. Journal of Hospitality and Tourism Management, 39, 150-157. doi: https://doi.org/10.1016/j.jhtm.2019.04.006

Kulkarni, K. K., Kalro, A. D., Sharmaa, D., \& PiyushSharma. (2019). A typology of viral ad sharers using sentiment analysis. Journal of Retailing and Consumer Services. doi: https://doi.org/10.1016/j.jretconser.2019.01.008

Mishra, A., Maheswarappa, S. S., Maity, M., \& Samu, S. (2018). Adolescent's eWOM intentions: An investigation into the roles of peers, the Internet and gender. Journal of Business Research, 86, 394-405. doi: https://doi.org/10.1016/j.jbusres.2017.04.005

Mostafanezhad, M., \& Norum, R. (2018). Tourism in the post-selfie era. Annals of Tourism Research, 70, 131-132. doi: https://doi.org/10.1016/j.annals.2017.11.008

Relling, M., Schnittka, O., Sattler, H., \& Johnen, M. (2016). Each can help or hurt: Negative and positive word of mouth in social network brand communities. International Journal of Research in Marketing, 33(1), 34-58. doi: https://doi.org/10.1016/j.ijresmar.2015.11.001

Sigala, M. (2018). \#MeTourism: the hidden costs of selfie tourism. Retrieved August 8th, 2018, from http://theconversation.com/metourism-the-hidden-costs-of-selfie-tourism-87865

Trinanda, O., \& Mutaqin, P. D. (2019). The Influence of Electronic Word of Mouth Toward Destination Trust and Travel Intention on Sirandah Island in Padang City. ECo-Buss, 1(3), 140151. doi: https://doi.org/10.32877/eb.v1i3.60

Wardi, Y., Abror, \& Trinanda, O. (2018). Halal tourism: antecedent of tourist's satisfaction and word of mouth (WOM). Asia Pacific Journal of Tourism Research. doi: https://doi.org/10.1080/10941665.2018.1466816 